\title{
ROMPENDO O SILÊNCIO: \\ A participação feminina no Movimento Operário de Rio Grande-Pelotas (1890-1920)'
}

\section{Maria Amélia Gonçalves da Silva ${ }^{2}$}

Nas últimas décadas do séc. XIX e primeiras do séc. XX, o Brasil passou por um período acelerado de transformações, tendo o processo de industrialização participado da mudança da fisionomia das cidades, das formas de pensar e de agir de seus habitantes.

É consensual na historiografia brasileira referir que a primazia no desenvolvimento industrial brasileiro coube aos estados do Rio de Janeiro e São Paulo ${ }^{3}$. Estes estados foram acompanhados pelo Rio Grande do Sul que, embora agro-pastoril por excelência, desenvolveu a partir da segunda metade do séc. XIX seu parque industrial, tendo se intensificado o ritmo de crescimento fabril na passagem para o séc.

1 Este artigo foi elaborado tendo por base o terceiro capítulo de minha dissertação de mestrado junto ao CPGH-PUCRS, sob a orientação da Profa. Dra. Margaret M. Bakos, e que se encontra em fase final de redação.

2 Mestranda do Curso de Pós-Graduação em História da PUCRS.

3 Não cabe, nos limites deste trabalho, discorrer sobre as razōes que proporcionaram a primazia do desenvolvimento industrial aos estados de São Paulo e Rio de Janeiro. Numerosos são os trabalhos que se ocupam dessa temática e, entre outros, podemos citar: SILVA, Sérgio. Expansão cafeeira e origens da indústria no Brasil. São Paulo: Alfa-Ômega, 1976; DEAN, Warren. A industrialização de São Paulo. São Paulo: DIFEL, 1971; CANO, Wilson. Raízes da concentração industrial em São Paulo. São Paulo: DIFEL, 1977; PEREIRA, Luis Carlos Bresser. Empresários e administradores no Brasil. São Paulo: Brasiliense, 1974; FOOT, Francisco \& LEONARDI, Victor. História da indústria e do trabalho no Brasil. São Paulo: Global, 1982. 
$\mathrm{XX}$, quando chegou a figurar em terceiro lugar no Censo Industrial do Brasil de $1907 .{ }^{4}$

Rio Grande e Pelotas constituíram-se em centros industriais do estado e logo passaram a ostentar os sinais da sociedade urbanoindustrial que se formava. No final do séc. XIX, estas cidades contavam com fábricas têxteis, de vestuário, alimentação e fumageira, entre outras. A falta de dados mais precisos sobre o operariado empregado na região dificulta a tarefa do pesquisador. Mesmo assim, as parcas estatísticas disponíveis atestam que boa parte da mão-de-obra utilizada no parque industrial de Rio Grande/Pelotas era formada por mulheres. O Censo de 1920 mostra a seguinte situação:

\section{Quadro 1}

Operariado das cidades de Pelotas e Rio Grande conforme sexo

\begin{tabular}{|c|c|c|c|}
\hline CIDADE & MULHERES & HOMENS & TOTAL \\
\hline PELOTAS & 2.043 & 4.376 & 6.419 \\
\hline RIO GRANDE & 2.223 & 4.325 & 6.548 \\
\hline
\end{tabular}

Fonte: Recenseamento do Brasil (1920): população. In: De Província de Săo Pedro a Estado do Rio Grande do Sul (Censos de 1803-1950). Porto Alegre: FEE, 1981, p. 133.

Como se pode perceber, a diferença numérica entre o operariado das duas cidades é ínfima, mantendo-se também a mesma proporção de mulheres empregadas nas duas localidades. Dessa forma, as mulheres compunham cerca de um terço da mão-de-obra industrial desses dois municípios, o que certamente não é um número que possa ser desconsiderado.

Temos assim um contingente nem um pouco desprezível - mas desprezado - de trabalhadoras anônimas, esquecidas pela historiografia até bem pouco tempo atrás. Mesmo desempenhando tarefas desprestigiadas, essas operárias faziam parte da parcela economicamente ativa do país, contribuindo para o seu crescimento, sem terem valorizada sua condição de sujeitos da História.

Juntamente com o surto industrial e intimamente ligado a ele, surgiram também as primeiras tentativas desferidas pelos trabalhado-

4 MINISTÉRIO DA AGRICULTURA, INDÚSTRIA E COMÉRCIO: Diretoria Geral de Estatística. Annuário Estatístico do Brazil (1908-1912). Rio de Janeiro: Typografia de Estatística, 1917, vol. 2. 
res fabris contra o capital. Os operários não tardaram em organizar sociedades de auxílio mútuo e de caráter político, desempenhando o jornal e o teatro operário um relevante auxílio para esta organização e para a divulgação de idéias norteadoras da luta operária. ${ }^{5}$ Os anos entre 1890-1920 foram profícuos em manifestações de confronto entre a burguesia industrial e a classe operária, constituindo-se a greve o seu momento mais extremo.

As mulheres também estiveram presentes nesses confrontos. A notícia mais remota obtida da participação de operárias em movimentos grevistas data de 1890 e trata-se de uma greve deflagrada pelos tecelóes da fábrica Rheingantz, que tinha como principal reivindicação a demissão de um inspetor pelo péssimo tratamento que dispensava aos operários. O movimento paredista manteve-se durante cerca de sete dias e contou com a participação de mais de quatrocentos operários - "entre homens, mulheres e crianças" ", não obtendo os grevistas o fim almejado. A volta ao trabalho deu-se mediante a participação dos redatores dos jornais rio-grandinos Echo do Sul, O Artista e Diário do Rio Grande, que agiram como mediadores do conflito e teve como saldo a demissão de oito operários. ${ }^{7}$ Outra greve com participação feminina data de 1901, também na cidade de Rio Grande, envolvendo desta vez tecelãs da Fábrica Ítalo-Brasileira, por motivos salariais. ${ }^{8}$

Mas as notícias mais expressivas da participação das operárias rio-grandinas e pelotenses em movimentos grevistas data do convulsionado 1917 - ano em que, por todo o país, o que não faltavam eram notas sobre greves, assembléias operárias, confrontos entre a polícia e os trabalhadores.

Assim, em reunião realizada na cidade de Pelotas, em agosto de 1917, em meio à greve geral que sacudiu os centros industriais do país, encontramos a operária Amélia Gomes discursando entre tantos

5 JARDIM, Jorge Pastorisa. Comunicaçāo e militância: a imprensa operária do Rio Grande do Sul. CPGH-PUCRS: Porto Alegre, 1990 (dissertação de mestrado).

LIMA, Mariangela Alves de \& VARGAS, Maria Thereza. "Teatro Operário em Sāo Paulo". In: PRADO, Antonio Arnoni. Libertários no Brasil. São Paulo: Brasiliense, 1986, p.162-250.

6 Correio Mercantil, Pelotas, 2/7/1890.

7 Correio Mercantil, Pelotas, 2/7/1890 a 9/7/1890.

8 A Opinião Pública, Pelotas, 10/4/1901. 
outros líderes do movimento operário, "concitando as suas companheiras a se congregarem em torno dos trabalhadores a fim de lutarem em prol da felicidade e bem-estar de seus lares" ${ }^{\text {. Cabe salientar }}$ que a reunião foi tão concorrida que a sede da Liga Operária foi pequena para o afluxo de público, o que acarretou a transferência da reunião para a via pública. Entre as reivindicações dos trabalhadores encontravam-se medidas contra a "carestia", tais como aumento de salários, controle dos preços dos aluguéis, barateamento de gêneros alimentícios básicos, bem como a regulamentação da jornada de trabalho de 8 horas diárias - para mulheres e menores, jornada de 6 horas e proibição do trabalho de menores de 14 anos. ${ }^{10}$

Dias depois, em assembléia na Liga Operária, discursou outra operária da Fábrica Fiação e Tecidos, era Clementina Silva Ramos, “... que reclamava por suas colegas o aumento de salários, visto que eram obrigadas a fazerem 200 carretéis para ganharem 2.000 réis, $e$ as que fizessem menos de 200 carretéis só ganhariam 1.000 e, que se por acaso chegassem um pouco mais tarde da hora de entrada, sofreriam uma multa de 2.000" 11 . Além de discursos inflamados, denunciando a exploração a que eram submetidas e da conclamação de suas companheiras à luta, essas mulheres não fugiam aos confrontos diretos com a repressão policial.

Em Rio Grande, em 1919, ocorreu mais um movimento paredista de vulto, envolvendo novamente as operárias da União Fabril: às 12 horas do dia 8 de maio, uma comissão de grevistas, composta por homens e mulheres, compareceu à fábrica e postou-se à frente do portão de entrada para."convidar" seus companheiros a aderir à greve. Segundo fonte pesquisada, o piquete funcionou, pois o portão foi fechado. Nesse momento um operário proferiu um "viva às oito horas de trabalho", o que resultou numa carga da cavalaria da polícia, que investiu contra os operários, ferindo algumas mulheres. Logo depois, um praça da força policial disparou um tiro, dispersando os presentes. ${ }^{12}$ Mesmo assim, refere o artigo:

“... pouco depois reuniram-se novamente tendo uma das operárias da Uniấo Fabril dirigido a palavra às suas colegas. No-

\footnotetext{
9 A Opinião Pública, Pelotas, 6/8/1917.

10 Ibidem.

11 Echo do Sul, Rio Grande, 13/8/1917.

12 Echo do Sul, Rio Grande, 8/5/1919.
} 
vamente a polícia interveio efetuando as prisōes dos operários Henrique Barros e Adalberto Marcelino de Carvalho. Numerosos operários e operárias seguiram os seus companheiros presos dando vivas à greve $\mathrm{e}$ às 8 horas. Ao passarem pela rua marechal Deodoro esquina Vice Almirante Abreu, os grevistas protestaram contra a arbitrária prisāo, tendo a polícia em resposta dado uma descarga sobre aqueles. Os operários responderam a pedradas a essa atitude da polícia."13

Operárias participando de reuniões, piquetes, enfrentando a polícia com palavras e pedras. Imagem certamente desconcertante para quem as queria sexo frágil, submissas e atemorizadas.

Mas, além das greves, quais as outras formas de participação feminina no movimento operário de Rio Grande/Pelotas?

Algumas pistas são apontadas pelos jornais operários.

Nos poucos exemplares existentes do jornal anarquista $A$ Luta de Pelotas, alguns artigos destacam-se para a elaboração do presente trabalho: são os da militante Maria Antônia Soares. Nascida na cidade de Santos, Maria Antônia juntamente com sua mãe Paula Soares e suas irmãs Maria Angelina, Matilde e Pilar aderiu - a contragosto do marido e pai muito católico - às idéias libertárias do enteado e meioirmão, Florentino de Carvalho. Logo a "Casa de Paula Soares", como ficou conhecida, tornou-se centro difusor do anarquismo, ocupando Maria Antônia um lugar proeminente na militância local. Transferindo-se, em 1914, para o bairro do Brás, na cidade de São Paulo, a casa da família Soares transformou-se em reduto e refúgio de militantes anarquistas, além de ponto de encontro, escola e redação de jornais libertários. Em 1923, a família mudou-se para o Rio de Janeiro, onde continuou suas atividades. ${ }^{14}$

Ativa participante do Centro Feminino Jovens Idealistas de São Paulo, que ajudou a fundar, Maria Antônia Soares logo destacou-se juntamente com sua irmã Angelina - na propagação do anarquismo, seja através de atividades de cunho político-culturais, seja promovendo manifestações públicas de denúncia, de apoio a greves e de protes-

13 Ibidem.

14 CORREIA, Francisco. "Mulheres anarquistas". In: Coleção Remate de Males. № 5, Instituto de Estudos da Linguagem, Departamento de Teoria Literária, UNICAMP, Campinas, 1985, p. 51-52. 
tos contra deportações, o que lhe valeu uma temporada na prisão no ano de 1920, juntamente com outros militantes. ${ }^{15}$

Além das encenações teatrais e palestras que proferia, Maria Antônia continuamente tomava a pena e defendia suas idéias em jornais libertários. Foi através de seus artigos que ficou registrada a existência do Centro Feminino de Estudos Sociais em Pelotas, assim como são também eles que permitem tecer algumas considerações sobre a forma de participação feminina no movimento operário da região, bem como sobre as dificuldades encontradas por essas mulheres que não se contentavam em ser apenas operárias submissas e morigeradas, esposas cordatas ou mães dedicadas.

O primeiro artigo de Maria Antônia Soares, publicado no jornal pelotense $A$ Luta, está sob forma de carta endereçada às integrantes do Centro Feminino de Estudos Sociais. Ocupando um espaço considerável - cerca de 3 colunas nas páginas centrais do periódico - a autora exorta suas companheiras de luta a perseverarem frente aos obstáculos encontrados, embora estes não sejam claramente declinados no texto.

Segundo esse artigo, as militantes pelotenses teriam escrito ao Centro Feminino de São Paulo comunicando a fundação de um grupo similar em Pelotas e, pouco tempo depois - não precisando exatamente quanto -, teriam novamente escrito participando o seu fechamento. Ao que, evidentemente, Maria Antônia se opõe, evidenciando em sua argumentação, contrária à dissolução do Centro, os objetivos dessas associaçōes:

"Ele [o Centro Feminino de Estudos Sociais de Pelotas] foi fundado, como o de São Paulo, com o fim de despertar no elemento feminino no Brasil algum interesse pelas questōes sociais. (...). Vós quando fundasteis o vosso centro, e nós aqui quando fundamos o nosso, idealizamos um vasto programa, onde transpareciam todas as nossas sublimes aspiraçōes de libertárias. Propuzemo-nos a contribuir para a realizaçấo de grande ideal de liberdade com que sonhamos, levando às almas femininas um pouco de luz. Infiltrando-lhes um pouco desse ideal."16

Em outro trecho da referida carta, pode-se perceber as estratégias encontradas para vencer a resistência do meio social quanto à existência de tais grupos:

\footnotetext{
15 Ibidem, p. 49.

16 A Luta, Pelotas, 31/5/1916.
} 
"Para nós, que já nos interessamos mais ou menos, temos os vários centros libertários onde podemos perfeitamente empresar a nossa atividade. Nós näo precisamos dos centros exclusivamente femininos pois que não vemos a necessidade (de nossa parte) de estabelecer, na luta, uma linha divisória entre os dois sexos, sendo as aspiraçōes as mesmas.

Se os centros femininos constituem uma necessidade, é devido a ser a única forma de atrair ao nosso meio, o elemento feminino.

Era esse, justamente o fim do Vosso Centro, a missão que vos propusestes ao fundá-lo. Atrair as mulheres dessa cidade, desse Estado, mesmo, fazê-las interessar-se pelos ideais que queremos propagar"17

Embora as idéias libertárias tivessem um caráter universalista e igualitário - e a articulista deixa bem claro a sua posição -, a menção da necessidade que esses grupos de estudo, pelo menos no início de suas atividades de propaganda, contassem apenas com elementos do sexo feminino demonstra uma concessão à sociedade e à moral que pretendiam abolir. Ao fundar um grupo de estudos estritamente feminino, cumpria-se com uma exigência da moral burguesa, que via perigo na reunião de ambos os sexos - principalmente se os componentes fossem jovens -, criando-se um espaço para a propagação de idéias emancipatórias. Esse trecho também faz pensar na existência de um certo número de "iniciadas", que comporiam a liderança local e que tinham como tarefa arregimentar novas adeptas, mesmo que para tal tivessem que se enquadrar à moral sexual vigente. Um grupo dedicado a assuntos culturais composto apenas por mulheres evitava falatórios e suspeitas. Essa prática funcionava como uma estratégia onde, utilizando-se dos espaços deixados pelo status quo engendrava-se uma forma de subvertê-lo.

Maria Antônia termina a carta exortando suas companheiras a continuarem na luta, com palavras de otimismo e esperança de dias melhores.

Embora não seja publicada mais nenhuma notícia sobre o prosseguimento do trabalho do Centro Feminino de Estudos Sociais de Pelotas, é provável que ele não tenha sido desfeito por completo, pois, nos números seguintes do jornal, continuam sendo publicados artigos referentes à promoção social da mulher - em especial da operária - 
assinados por Maria Antônia. E mesmo que o Centro tenha encerrado suas atividades enquanto tal, o interesse de suas idealizadoras certamente permaneceu, o que explicaria a manutenção de sua coluna.

Embora o artigo citado refira-se à pouca duração desse grupo libertário feminino, alguns indícios sugerem que esta não foi assim tão efêmera. Em artigo intitulado Mulheres Anarquistas, Francisco Correia informa-nos que em outubro de 1915, no Rio de Janeiro, realizou-se o Congresso Internacional da Paz, organizado por membros da Federação Operária do Rio de Janeiro, que contou com a participação de várias lideranças femininas. Maria Antônia Soares esteve presente nesse congresso, juntamente com Eliza Gonçalves de Oliveira que "falou em nome do Centro Feminino de Estudos Sociais, de Pelotas, evidenciando a posição inconfundivel da mulher anarquista contra a guerra" 18 . Como a carta de Maria Antônia Soares, mencionando a decisão de fechamento do Centro, data de maio de 1916, tem-se, no mínimo, um lapso de sete meses durante o qual teria funcionado o grupo anarquista feminino pelotense. Porém, o seu período de funcionamento pode ter sido maior, pois a participação de uma representante, em 1915, junto à Federação Operária do Rio de Janeiro, pressupõe uma certa organização, não apenas para fazer frente às despesas com a longa viagem, como também para o preparo da emissária que iria apresentar a posição do Centro frente ao tema principal discutido por esse Congresso: o pacifismo.

Além disso, em 1914, o movimento operário de Pelotas passou a contar com o Centro de Estudos Sociais de Pelotas - que funcionava, então, na sede da Liga Operária e do qual participavam vários líderes anarquistas $^{19}$. Neste ano fundou-se, também, o Grupo Iconoclasta, que foi o responsável pela publicação do jornal anarquista A Luta, de Pelotas - jornal esse que publicava os textos de Maria Antônia Soares. Além dessas duas entidades, também são fundados o Ateneu Sindica-

\footnotetext{
18 CORREIA, loc. cit., p. 51.
}

19 Entre esses estava Zenon de Almeida, um dos mais ativos militantes anarquistas do estado. Casado com a também anarquista, Eulina Augusta - uma das famosas "irmãs Martins"- desenvolveu sua militância alternadamente nas cidades de Pelotas, Rio Grande e Porto Alegre entre 1913 e 1919, quando foi deportado pelo governo borgista para Sảo Paulo, transferindo-se depois para o Rio de Janeiro. É apontado por Joāo Batista MARÇAL em Os Anarquistas no Rio Grande do Sul (POA: Unidade Editorial, 1995, p. 35-36), como um dos responsáveis pela fundação do Grupo Iconoclasta e redação do $A$ Luta, entre outras atividades. 
lista Pelotense e o Grupo de Teatro Social $1^{9}$ de Maio, ambos ligados ao atuante Grupo Iconoclasta. Já em 1915, esse mesmo grupo também se fez representar junto ao Congresso Internacional da Paz através de Pedro Bischoff e Santos Barbosa. ${ }^{20}$ Certamente esses foram companheiros, não apenas de luta em Pelotas, como também de viagem ao Rio de Janeiro da militante Elisa Gonçalves de Oliveira.

Portanto, num cálculo aproximado, seria lógico apontar um período variável entre sete meses e dois anos para o funcionamento do Centro Feminino de Estudos Sociais.

Considerando-se a constante carência de recursos e as dificuldades inerentes ao movimento operário da época, a existência de um grupo feminino para estudo e discussão de idéias libertárias e emancipatórias da mulher durante esse lapso de tempo não pode passar despercebida nem ser menosprezada.

Embora a notícia do funcionamento desse grupo tenha sido preservada a partir da sua dissolução - o que não deixa de ser paradoxal e sejam poucas as referências que temos sobre sua atuação, o fato de ter existido permite algumas certezas: em primeiro lugar, a de que os homens, fomentadores do movimento operário local, não estavam sozinhos em suas atividades. Contavam com a participação de mulheres que, rompendo com barreiras e convenções ligadas a seu sexo, reuniam-se para discutir não apenas a sua condição, como também difundir idéias de liberdade e justiça social ou - como queria Maria Antonia Soares - levar "às almas femininas um pouco de luz" ${ }_{21}$. Em segundo lugar, a certeza de que elas, por sua vez, também não estavam sozinhas e isoladas. A troca de correspondência com uma ativa militante libertária de São Paulo, a presença constante de seus artigos no jornal operário local, bem como a participação de uma representante em congresso realizado na capital do país, mostram o constante diálogo e intercâmbio de idéias existentes entre elas. Qual era o teor dessas idéias? Os artigos de Maria Antônia Soares fornecem algumas pistas.

A primeira preocupação que transparece nos seus textos é a da crescente participação feminina no mercado de trabalho. Aponta como causa imediata dessa situação a necessidade da mulher contri-

20 MARÇAL, Joāo Batista. Primeiras Lutas Operárias no Rio Grande do Sul. Porto Alegre: Livraria do Globo, 1985, p. 11. 
buir para o sustento de sua família, evocando para tal os papéis tradicionalmente reservados à mulher. Assim, a mulher:

"Esposa e mấe, viu-se obrigada a abandonar o lar e buscar meios de contribuir também para o sustento da família por ser o ganho do marido demasiado mesquinho. Filha e irmã, viu a necessidade de acorrer ao sustento dos velhos pais inutilizados para o trabalho por terem empregado nele mais força do que dispunham e a seus irmâozinhos, demasiadamente pequenos ainda para se sustentarem a si próprios.

A necessidade obrigou-a ao excessivo trabalho das fábricas, de todos os lugares, enfim, onde pudesse ganhar o pāo que em casa faltava. ${ }^{22}$

Ao evocar logo no início do texto, as imagens da mulher mãe, esposa, filha e irmã sofredora, que abandona o lar premida pelas circunstâncias financeiras desfavoráveis, sacrificando-se em nome dos que ama, a autora socorre-se numa imagem familiar ao leitor, evocando também o seu sentimentalismo, numa tentativa de quebrar sua possível resistência quanto a uma mensagem de libertação feminina. Tal como a idéia de grupos apenas femininos para estudo das idéias libertárias, esboça-se uma outra estratégia: a utilização de uma imagem já cristalizada no imaginário social - a da santa mãezinha, da filha ou irmã angelical, da esposa dedicada - que é subvertida em favor de uma maior liberdade feminina. Deve ter-se em mente que uma das preocupações constantes do meio operário da época era a menor oferta de trabalho e/ou o rebaixamento dos salários que poderiam sobrevir à utilização da mão-de-obra feminina e infantil. E é exatamente sobre a natureza dessa pretensa competição que Maria Antonia Soares desenvolve seus artigos. Certamente por isso, a necessidade de cooptar o leitor, antes de tocar em um assunto tão delicado.

Concordando com a idéia de que a competição oriunda do emprego de mão-de-obra feminina nas indústrias pudesse desencadear algum aumento do desemprego masculino e "causar certa perturbação na vida econômica dos lares proletários” ${ }^{23}$, Maria Antonia recusa a idéia de que o trabalho feminino se constitua, por si, necessariamente um mal, mas sim, juntamente com a educação, no meio neces- 
sário para a emancipação da mulher. Ela deixa bem claro essa posição ao dizer que:

"Se a mulher ganhasse o suficiente para o seu sustento, estaria já na metade do caminho para a sua emancipaçâo.

Não precisando do homem para a vida material, não teria porque escravizar-se moralmente. Restar-lhe-iam somente alguns preconceitos que viriam a desaparecer com o tempo, quando, livre já da tutela do homem, pudesse instruir-se livremente.

Isto foi previsto por aqueles que ganham com a ignorância alheia e por isso tratam de impedir que tal coisa se realize."24

As razões que aponta para o prejuízo causado ao operariado pela entrada da mulher nas fábricas estariam ligadas à exploração imposta pelo sistema capitalista que se basearia na "debilidade dela [a mulher] e no egoísmo do homem" que "abandonando as suas companheiras à iníqua exploração de que são objeto em virtude de sua ignorância e impotência permanecendo apáticos diante da ação burguesa que os some na miséria e na vergonha. ”25

Como solução para esses males, essa libertária propõe a união dos trabalhadores de ambos os sexos, sustentando a idéia de que homens e mulheres devem ser solidários na luta que levará à transformação social. Essa tarefa caberia à mulher por ser ela quem "desde os primeiros tempos sofre os aviltantes ultrajes da mais infame organização social. ${ }^{26}$

$\mathrm{O}$ atrelamento da emancipação feminina à emancipação das classes trabalhadoras e à transformação social como um todo, longe de tratar-se de pensamento original de uma militante isolada, refere-se a uma idéia recorrente no pensamento das mulheres libertárias ${ }^{27}$. Uma companheira de luta de Maria Antônia Soares definiu da seguinte forma essa questão:

“A emancipação da Mulher não está na igualdade desta perante o homem, nas prerrogativas políticas, de mando e de trabalho, mas sim na emancipação da humanidade da tutela política e na Igualdade econômica e social de todo o gênero humano.

\footnotetext{
24 A Luta, 15/7/1916.

25 Ibidem.

26 Ibidem.

27 CORREIA, Francisco. "Mulheres libertárias: um roteiro". In: PRADO, Antonio Arnoni. Libertários no Brasil. Sāo Paulo: Brasiliense, 1986, p. 49.
} 
(...)

Igualá-la aos homens é ficar onde estamos. Nós devemos é lutar ao seu lado e junto aos homens para que a emancipaçẫo seja um fato, nẩo para a mulher, ou para o homem, mas para todas as pessoas (inclusive crianças e adolescentes), para a Humanidade, porque os dois sexos se integram e se completam." 28

Apesar de professarem essas idéias, é novamente Maria Antonia que mostra o quanto os seus sonhos de igualdade e companheirismo entre homens e mulheres estavam longe de se concretizar. Seu discurso enche-se de tons agressivos - mais do que os dispensados aos capitalistas - quando se refere ao desprezo demonstrado por aqueles que viam na eloqüência feminina, posta a serviço de sua independência, motivo de zombaria. Sem "meias-palavras", Maria Antonia Soares fulmina:

Tenho observado que quando alguma de nós mulheres dá uma opiniāo, ou presta o seu concurso em um ato qualquer de propaganda emancipadora, não falta algum imbecil (eu assim considero) que deixe assomar aos lábios um sorriso zombador, e chegam algumas vezes a patentear verbalmente, por meio de sandices, o desprezo que lhe inspira a açāo daquela mulher.

Eu reconheço que os que isto fazem, ou são demasiado ignorantes ou hipócritas, e em qualquer dos dois casos só podem merecer a nossa compaixão. ${ }^{29}$

Tal como Maria Antonia Soares e suas companheiras do Centro Feminino de Estudos Sociais de Pelotas, mesmo enfrentando o "sorriso zombador", "as sandices" ou "o desprezo", outras mulheres não se deixavam calar. Este é o caso de Agostina Guizzardi.

No início desse século, a libertária Agostina Guizzardi lecionva, proferia discursos, escrevia. O primeiro contato com Agostina deu-se através do único exemplar encontrado do jornal rio-grandino $O$ Proletário, onde, além de figurar em duas notícias, assinava um artigo em que transparecem suas atividades como militante no movimento operário local.

28 Trecho do discurso proferido por Isabel CERRUTTI na inauguraçăo do Centro Feminino de Educação de São Paulo reproduzido por Francisco CORREIA, loc. cit., p. 55-56.

A Luta, Pelotas, 31/7/1916. 
Neste número do jornal, numa pequena nota, os redatores recomendavam aos operários a escola de italiano e português que seria brevemente inaugurada pela "companheira" Agostina Guizzardi; em outra seção, noticiavam a encenação de uma de suas peças teatrais, e, por fim, era publicado um artigo da própria Agostina Guizzardi. ${ }^{30}$

Sob o título de $\mathrm{Na}$ União Operária, Agostina discorre sobre uma festa realizada em homenagem a um marinheiro português que estava de passagem pela cidade. ${ }^{31}$ A solenidade teria contado com a encenação, pela segunda vez, da peça A Honra Proletária, de sua autoria, bem como da entrega de "um valioso mimo" e discursos. E é exatamente sobre o teor desses discursos que Agostina Gizzardi se insurge. Segundo afirma, os componentes da diretoria da União Operária teriam sido incoerentes com o internacionalismo da luta operária ao darem uma conotação patriótica ao evento, através da exaltação da ligação Brasil/Portugal. Criticava Agostina:

"Ignorava talvez a comissão promotora que o talento é cosmopolita e a União Operária uma associação internacional? Esqueceram-se de que festejavam um filho do povo distinto, e não a nacionalidade portuguesa?

Sentimos bastante que a nossa humilde pena seja obrigada a traçar sempre amargas frases de censura, ainda da única sociedade operária existente nessa cidade, e desejaríamos de toda alma, tecer com ela unicamente coroas de palmas e encorajamentos; mas, estamos acostumadas a dizer sempre a verdade, e continuaremos sejam quais forem os obstáculos que se nos depararem no caminho.

E a nossa censura, o nosso voto de pesar por tanta ignorância, estende-se não somente a todos os sócios que foram espectadores inconscientes, mas também à diretoria da sociedade, a qual rememoramos mais coerência com os idéias que pretendem defender." 32

Juntamente com esta ácida censura, Agostina demonstra a sua independência intelectual dos líderes da União Operária, afirmando a

30 O Proletário, Rio Grande, 28/1/1906.

31 A identidade do homenageado não é declinada no texto, onde é chamado apenas por "marinheiro 47". Mas, tudo leva a crer que constituia-se em importante ativista do movimento operário pelas honrarias que lhe foram dispensadas pela União Operária. 
necessidade de exprimir suas opiniōes, sem recear "melindrar a quem quer que seja" ${ }^{33}$. O que não quer dizer que não sofresse as pressōes de um meio fortemente marcado pela indiferença e preconceito de seus pares do sexo oposto, pois, mesmo afirmando sua autonomia, Agostina Guizzardi demonstra lucidez quanto aos limites a que estava submetida a força de sua voz quando, no final de seu texto, desabafa:

"Sabemos perfeitamente que falamos no deserto, mas mesmo assim gritaremos cada vez mais, na esperança que no meio da aridez da inconsciência, ligada à mais imperdoável apatia, existe ainda alguns oásis, verdejantes de dignidade no pleno sentido da palavra. Às vezes, tanto se grita, até que alguém se acorda." 34

Apesar das críticas - ou até, quem sabe, por causa delas - Agostina Guizzardi gozava de certo prestígio no movimento operário riograndino. $O$ Proletário noticia que um drama de sua autoria - intitulado A Honra Operária - foi levado à cena na véspera do Natal de 1905 , no palco do salão da União Operária, sendo então muito aplaudido. Nesta mesma ocasiāo, Agostina teria recebido uma homenagem da União Operária que lhe ofertou um buquê de flores, contendo em uma das fitas que o decoravam uma mensagem de agradecimento. ${ }^{35}$ Quanto ao teor dessa peça teatral pouco se sabe, pois infelizmente nenhum exemplar foi localizado. Apenas informa o jornal que a peça “(...) visa a propaganda das idéias libertárias, convictamente professadas pela sua dedicada autora." ${ }^{36}$

Entretanto, em 1906, é publicado Amor e Ouro - drama social em 3 atos - que teria sido encenado pela primeira vez na noite de 27 de junho de 1903, no Teatro Politheama Riograndense. No seu elenco encontram-se ativos membros da União Operária e o redator do jornal Echo Operário, Antônio Guedes Coutinho.

Antes de comentar essa peça de Agostina Guizzardi, faz-se necessário tecer algumas considerações sobre o lugar ocupado e as características que o teatro assume dentro do movimento operário.

Em primeiro lugar, figuram a divulgação e o didatismo, pois é através das peças teatrais que os preceitos teóricos adotados pelo movimento operário são simplificados com o fim de atingir o maior

\footnotetext{
33 Ibidem.

34 Ibidem.

35 Ibidem.

36 Ibidem.
} 
número possível de trabalhadores. Apesar dos esforços dispendidos pelas associações operárias no sentido de fundar escolas e bibliotecas, o acesso aos livros era limitado. Ao analfabetismo e ao custo relativamente alto do livro para os bolsos proletários, somam-se a falta de traduções para o português das obras teóricas e a longa duração das jornadas de trabalho, que limitavam muito a disponibilidade para o lazer operário, sobretudo o tempo dedicado à leitura. Assim, o teatro, convenientemente aliava-se à educação e ao lazer, como demonstra um artigo publicado nessa época pela imprensa operária de Porto Alegre:

"O teatro é um complemento da escola. Durante o período da escolaridade ele contribui para a educação geral e artística da criança; posteriormente na vida pós-escolar, ele prolonga a educação e instrução das massas populares.

(...).

O teatro é a arte que mais influência direta tem nos povos e a que mais cai no íntimo das multidões que já atingiram um certo grau de civilização e que se aborrecem dos divertimentos de circo e de combates de touros (...).

A sua grande superioridade está em que é uma arte eminentemente social. O teatro efetiva-se diante de centenas de pessoas que comunicam entre si as idéias, os pensamentos, os sentimentos que vibram sobre a mesma sugestâo, debaixo dos mesmos determinantes!"37

Outra característica do teatro, clara no trecho acima, é a de facilitar o agrupamento de um considerável número de pessoas que recebem, de uma só vez, a mensagem. Esta, segundo o articulista - e a posição dominante no movimento operário - deveria mostrar a injustiça social, contribuindo para a criação da consciência de classe, sendo duramente criticadas as peças teatrais destinadas puramente à diversão:

"O que se vê são peças sem idéias, sem intuito educativo, unicamente com fins comerciais e glória fácil. O que predomina é a pornografia, a peça idiota cheia de concepçỏes disparatadas, verdadeiras sandices intelectuais e morais, explorando, sem filosofia nem literatura, todos os preconceitos, todas as reles tendências e baixas paixōes do ser humano. O sensualismo grosseiro de 
mulheres nuas, as situaçōes equívocas e os ditos de duplo sentido são os 'atrativos' obrigados de todas ou quase todas as peças que por esses palcos se exibem." ${ }^{\text {38 }}$

Posição próxima a esse autor, demonstram os redatores de $A$ Democracia Social. Sob o sugestivo título "Que Praga!" anunciam que:

"No Rio Grande tem se fundado atualmente umas seis ou oito sociedades dramáticas particulares, que só representam dramalhões da velha escola e comédias mais ou menos suporíferas, de nulo alcance social.

Por que não se dedicam a coisas mais úteis os moços que assim se dispōem a perder o melhor do seu tempo decorando declamaçôes e ensaiando lances tétricos de romances de Ponson de Terrail - vícios que depois trazem para a vida prática? ${ }^{39}$

Essa preocupação com o engajamento da arte dramática com a transformação social estava ligada à concepção anarquista, que via na expressão artística uma necessidade inerente à condição humana. Esta necessidade expressiva aliava-se, através das peças teatrais, à identificação de problemas comuns enfrentados pelos trabalhadores no seu cotidiano, procurando com isso despertar a consciência de classe. ${ }^{40}$ Assim sendo, geralmente a encenação teatral não ocorria sozinha, mas fazia parte de uma série de eventos programados pelas associações, combinando-se com conferências, apresentações musicais ou precedendo bailes.

Outra característica é a reprodução freqüente dos repertórios, pois o valor da peça teatral operária ligava-se mais ao seu caráter doutrinário, à clareza na transmissão de idéias que deviam embasar a prática cotidiana, do que propriamente com a qualidade estética. A repetição tornava-se "um ato coletivo de reconhecimento de personagens e situações exemplares a fim de que atuem no comportamento de cada um." ${ }^{41}$

Essa tendência presente no teatro operário de São Paulo, pode também ser observada em Rio Grande. Um exemplo é a peça de

\footnotetext{
38 Ibidem.

39 Democracia Social, Pelotas, 17/12/1893.

40 LIMA, Mariangela Alves de \& VARGAS, Maria Thereza. "Teatro Operário em Sāo Paulo". In: PRADO, op. cit., p. 167.

41 Ibidem, p. 187.
} 
Agostina Guizzardi, A Honra Proletária, que foi levada à cena duas vezes em curto espaço de tempo (véspera do Natal de 1905 e, novamente, em janeiro de 1906), sendo que na segunda vez fazia parte de uma programação mais ampla, onde foram proferidos discursos e prestadas homenagens a um militante.

Evidentemente, entre os assuntos tratados pelo teatro operário no Brasil estão a luta de classes - retratada a partir dos conflitos enfrentados pelos operários em seu cotidiano -, a árdua luta pela sobrevivência, a exploração patronal, a perseguição da polícia, bem como o anticlericalismo e temas relacionados aos costumes. Quanto a estes últimos, predomina a defesa da livre escolha do companheiro, tendo por base o afeto, não sendo rara a propaganda do "amor-livre" ${ }^{42} \mathrm{O}$ que não quer dizer que os valores pregados ficassem muito longe dos preconizados pela moral burguesa, pois monogamia, fidelidade, devoção e respeito dos filhos para com os pais freqüentemente são evocados nos dramas encenados nas entidades operárias.

A peça de Agostina Guizzardi, Amor e Ouro, não foge a essas características. A história gira em torno da desventurosa Ayda. Moça rica e generosa, Ayda apaixona-se por Jayme, cujo pai perdeu a fortuna recentemente. $\mathrm{O}$ namoro conta com a cumplicidade de Adolpho, seu irmão e confidente. Mas José, pai de Ayda, opōe-se ao namoro, acertando o casamento da filha com um jovem rico e insensível. Tudo isso, temperado pelas influências maléficas de um padre corrupto. A trama é simples e sua estrutura segue o folhetim com conversas escutadas atrás de portas, desencontros, cartas reveladoras, bem ao gosto da época.

Embora o tema principal seja a incompatibilidade existente entre o sentimento e as convenções sociais, o texto revela mais fortemente uma mensagem anticlerical e conclama à resistência feminina às imposições do patriarcalismo. Seguindo tendências do teatro operário, a autora não se preocupa com uma análise psico-social mais aprofundada de suas personagens. Basta-lhe o antagonismo maniqueísta: de um lado, as vítimas - neste caso, os apaixonados Ayda e Jayme, bem como Adolpho; de outro, o pai despótico, o pretedente ambicioso e o maléfico Padre Fernando.

Verdadeira encarnação do mal, o padre concentra toda a espécie de defeitos: revela segredos de confissōes de moças aos amigos; de- 
fende o casamento como uma aliança econômica, proferindo discursos contra o casamento interclasses. Autoritário e corrupto, sugere a José a internação de Ayda em um convento, para quebrar-lhe a resistência, bem como a "doação" de generosa soma, para perdoar-lhes os pecados.

É contra Padre Fernando que Ayda se insurge com mais veemência, conclamando:

"- Os pais de família que desejarem a honra e a tranqüilidade do próprio lar, devem fugir ao seu contato. A presença de homens que trazem sobre o corpo o negro manto da hipocrisia é sempre fatal..." 43

Mas se Ayda repele o Padre e o noivo com palavras duras, o mesmo não faz com seu pai. Tenta persuadi-lo, utilizando-se das "armas femininas": choro, desmaios, melancolia e, quando do confronto direto, tenta ludibriá-lo. Afinal, a firmeza da personagem em resistir a um casamento arranjado esbarra na idealização da figura feminina. Como heroína, a personagem criada por Agostina Guizzardi, não poderia correr o risco de indispor-se com o público. Assim, qualidades como generosidade, recato, ingenuidade, respeito ao pai são fundamentais para que a heroína não se torne antipática aos olhos do público e para que a mensagem de resistência contida na peça seja aceita.

Mas, mesmo após discussões acirradas, choros e desmaios, Ayda não consegue seu intento. O final trágico se aproxima. Ao sentir que perderia a batalha pela liberdade de escolher seu marido, Ayda lança mão do suicídio como último recurso. Através do aniquilamento físico, Angelina Guizzardi afirma a vitória moral de sua personagem sobre os seus opressores. A carta deixada por Ayda é lida no último ato e conclama à resistência todas as jovens que estivessem em semelhante situação. Dizia:

“ - ... Companheiras; a vós, enfim, um último adeus! Um último conselho: Se por acaso a sorte vos preparar um caminho tão espinhoso como aquele que eu trilhei: lutai, lutai com força, mas nunca vos torneis perjuras, porque o remorso matar-vos-ia! 
Lembrai-vos sempre desta infeliz, que neste extremo instante vos dirige o último adeus!..." 44

Resta apenas imaginar como teriam recebido a mensagem de Angelina Guizzardi as mulheres que estavam na platéia, quando o pano desceu no Politheama Riograndense, na longínqua noite de 27 de junho de 1903. A única certeza que fica é a de que seja proferindo palestra, discursando, escrevendo artigos para jornais operários, participando de centros de estudos libertários, escrevendo peças teatrais ou participando de movimentos grevistas, essas mulheres desafiavam com suas práticas as imagens que tentavam aprisioná-las. Queriamnas pacatas, submissas, frágeis, incapazes de gerir seus próprios destinos e elas disseram "não", afirmando-se, assim, como sujeitos de sua própria História. 